\title{
Tripartite symbiosis: shelter, hiding inhabitant, and ambush predator
}

\author{
Alexandra Migunova and Alexander Pinevich \\ Department of Microbiology, St. Petersburg State University, 199178, St. Petersburg, \\ Russia
}

| Submitted August 30, $2021 \mid$ Accepted September 17, 2021 |

\begin{abstract}
Summary
The article reviews current knowledge on the tripartite symbiosis: Paramecium bursaria-Chlorella sp.-virus PBCV. Special attention is paid to the studies initiated by Boris Gromov, and continued later, without his participation, at the Microbiology Department of St. Petersburg/Leningrad State University. Virus PBCV (Paramecium bursaria Chlorella virus), the type species of the genus Chlorovirus (Phycodnaviridae), belongs to the NCLDV group (nucleo-cytoplasmic large DNA-containing viruses). It has $100-400 \mathrm{~nm}$ size capside and $0.3-1.2 \mathrm{Mbp}$ dsDNA, and is highly specific, namely: only endosymbiotic algae (zoochlorellae) are infected. Moreover, the algae that stay within perialgal vacuoles are safe from infection while outside the damaged or dead host they are infected by absorbed virus particles. In a sense, PBCV takes position at the host's border, and "watches" on appearing algae (hence, figurative comparison with an ambush predator). In Russia, the symbiosis has been studied for three decades by the group headed by Gromov's collaborator Professor Konstantin V. Kvitko, and his partners. During this period of time (late 1980s - late 2010s), various aspects of tripartite symbiosis have been analyzed, such as: i) geographic distribution of the "American" ("south") and "Eurasian" ("north") ecotypes; ii) difference in serological characters and protein composition between different zoochlorellae ecotypes; iii) phylogenetic distinction of zoochlorellae deduced from rRNA genes similarity, and intron structure; iv) role of host exometabolites in the symbiosis; v) restoration of symbiotic system from algal strains marked with resistance to antibiotics; vi) ecological role of PBCV, as well as its influence on host evolution; vii) practical significance of $\mathrm{PBCV}$.
\end{abstract}

Key words: ciliates, endosymbiosis, NCLDV viruses, Paramecium bursaria, Chlorella sp., PBCV virus, zoochlorellae

\section{Introduction}

It sometimes happens so that the cooperation between specialists in different fields of biological science brings to a synergetic effect. Thus, in the middle 1980s, Professor Boris Gromov (who studied morphology of microscopic algae, symbiotic species in particular) participated in the analysis of water samples collected by the Russian Far East expedition headed by Professor Dmitri Ossipov (a prominent 

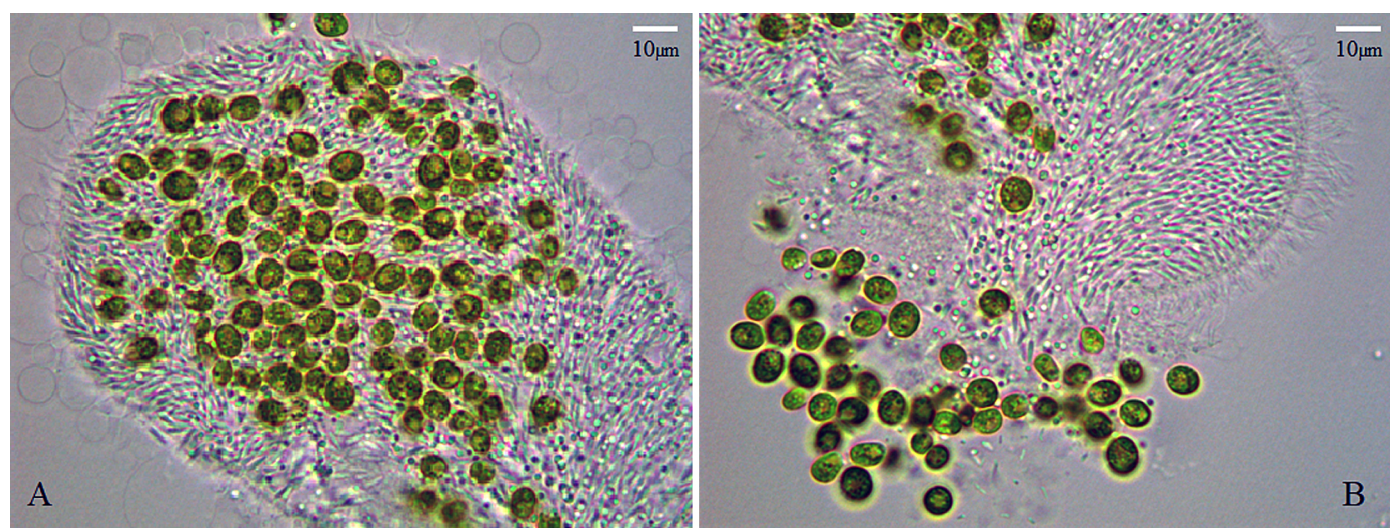

Fig. 1. Light micrograph of Paramecium bursaria and its endosymbiotic Chlorella. A - Intact host cell filled with zoochlorellae. B - damaged host cell, and falling out zoochlorellae.

researcher in protistan karyology). Fortunately, Gromov's close collaborator was Konstantin Kvitko, second professor at the Microbiology Department of St. Petersburg State University (he was also interested in unicellular green algae, although from a viewpoint of genetics and evolutionary ecology).

A special reason why K. Kvitko was intrigued by the analysis of "Russian" PBCV was explained by his being familiar with the report of Japanese authors (Kawakami and Kawakami, 1978) who described the virus, which formed the zones of lysis on lawns of the sensitive Chlorella strains isolated from ciliate cells. Taking into account a close proximity of Japan Islands and Russian Far East territories, it looked rather promising to find a "Russian" algal virus, and compare it with the "Japanese" counterpart.

Thus, the aforementioned water samples were tested not only for a presence of symbiotic microalgae (Gromov's personal interest), but also for a virus (Kvitko's personal interest). Intersecting interests of these two researches resulted in the discovery of new virus, which did not infect endosymbiotic "American" chlorellae, but attacked "Eurasian" strains. This finding was briefly reported (Kvitko and Gromov, 1984).

Being initially the "waste product" of Gromov's interest in microalgae, new virus has fortunately gained attention from Kvitko's group. Their study of the tripartite symbiosis has led to the deep insight into details of this remarkable association; the scientific epopee has lasted for nearly four decades, and one of this note's authors (A.M.) has been involved in it as early as from 1984.

To date, there is an impressive number of articles reviewing the tripartite symbiosis, and they regularly proceed to emerge (see Van Etten et al., 2020). In order to deter oneself from offering another duplicate, it seemed reasonable to focus on the studies initiated by Gromov and later continued without his participation.

\section{General properties of the tripartite symbiotic system}

Microscopic algae of the genus Chlorella (Trebouxiophyceae, Chlorellales, Oocystaceae) are very diverse and broadly distributed. Their ecotypes embrace planktonic, biofilm, soil, epilithic, and symbiotic variants. In the case of endosymbiosis, these algae not only respond to abiotic factors, but also adapt themselves to the conditions provided by host partner that results in the comparatively narrow specialization. This, on the one hand, constrains the distribution of algae, and on the other hand, helps them to gain foothold in specific niche.

The tripartite symbiotic system incorporating host ciliate Paramecium bursaria (Peniculia, Oligohymenophorea, Ciliophora), endosymbiotic "zoochlorella", and "phycovirus" infecting this alga is rare, sophisticated, and understudied. This association had been initially analyzed by German and American researchers (Reisser, 1980; Van Etten et al., 1981).

The partnership between paramecia and zoochlorellae is mutualistic: zoochlorellae fill the host cell (Fig. 1, A) and provide it with oxygen and carbohydrates, while paramecia supply the endosymbiont with carbon dioxide and products of nitrogen metabolism.

Viruses of the genus Chlorovirus (family Phycodnaviridae), in particular the type species Para- 

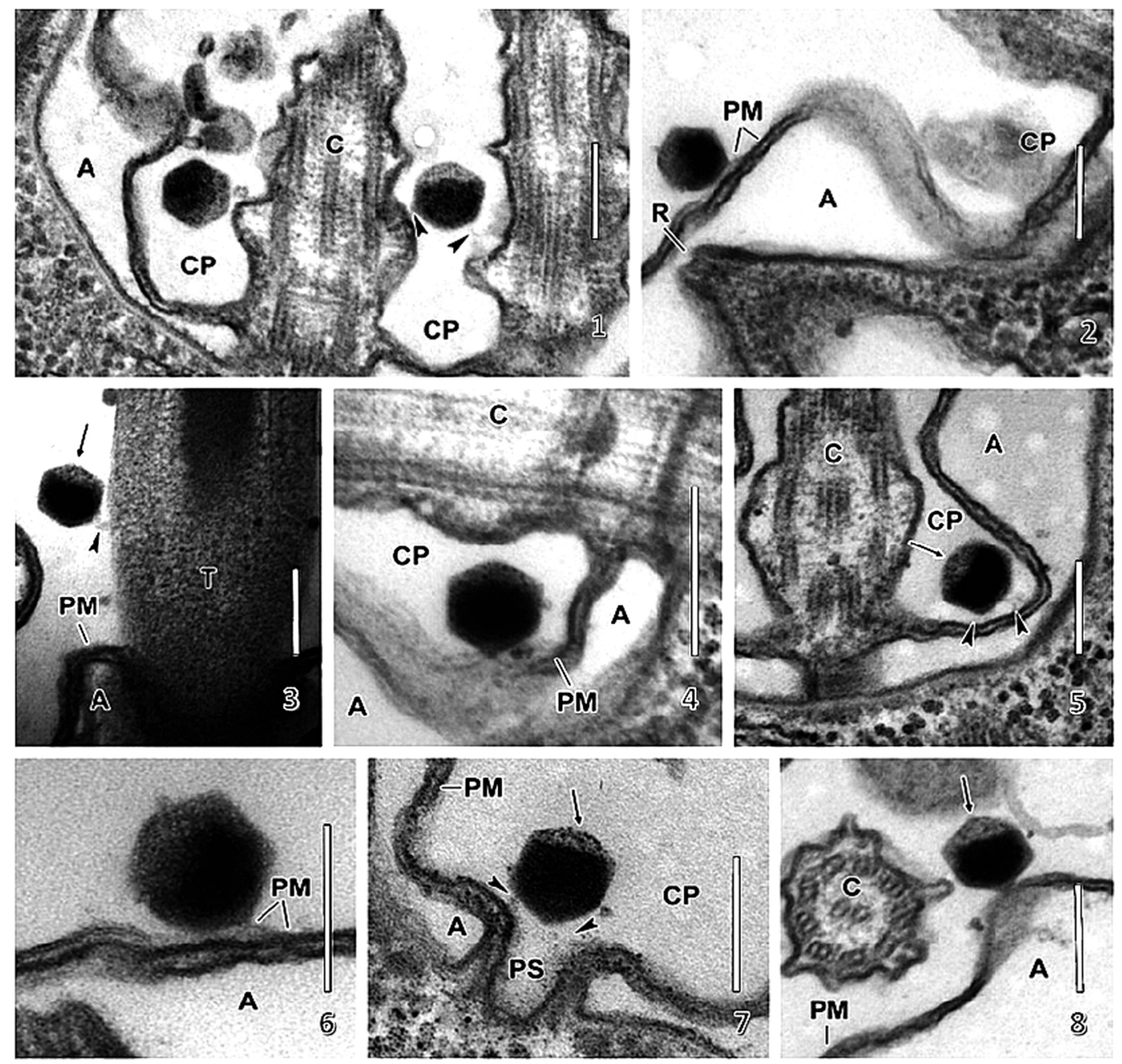

Fig. 2. Electron micrographs of PBCV associated with somatic cortex of Paramicium bursaria (kindly supplied by V.V. Yashchenko). Arrowheads indicate hair-like fibers connecting virus particles to plasma membrane. 1, 4, 5 - Longitudinal sections of cilia and virus particles; arrow indicates electron transparent vertex of the virus; 2, 6 - virus particles absorbed at plasma membrane; 3 - virus particles attached to an expulsive trichocyst; 7 virus within ciliary pits and near the entry into parasomal sac (endocytosis cite); 8 - virus particle attached to plasma membrane and cilia. Abbreviations: A - alveoli, C - cilia, CP - ciliary pits, PM - plasma membrane, PS - parasomal sac, T - trichocyst. Scale bars: $200 \mathrm{~nm}$.

mecium bursaria Chlorella virus (PBCV), belong to a group of "nucleo-cytoplasmic large DNA viruses" (NCLDV), which comprises the viruses with 100$400 \mathrm{~nm}$ size enveloped capsid, and 0.3-1.2 Mbp linear dsDNA genome.

PBCV is highly specific: it infects only zoochlorellae. Moreover, it attacks only free zoochlorellae, while zoochlorellae inside perialgal vacuoles (symbiontophores) are not infected. However, after the breakage of host envelope (e.g. due to cell damage or death) zoochlorellae pass into exoplasmic space
(Fig. 1, B) where they are attacked by virus particles absorbed onto surface receptors of a ciliate cell (Kawakami and Kawakami, 1978; Yashchenko et al., 2012), primarily at cilia or within invaginations of the cortex (Fig. 2). In a sense, PBCV takes a position at the host's border, and it "watches" on released algae (hence, figurative comparison with an ambush predator).

Besides the immobilized moiety, some of the virus particles are suspended in aqueous phase. After spreading of sampled water or infected culture onto 


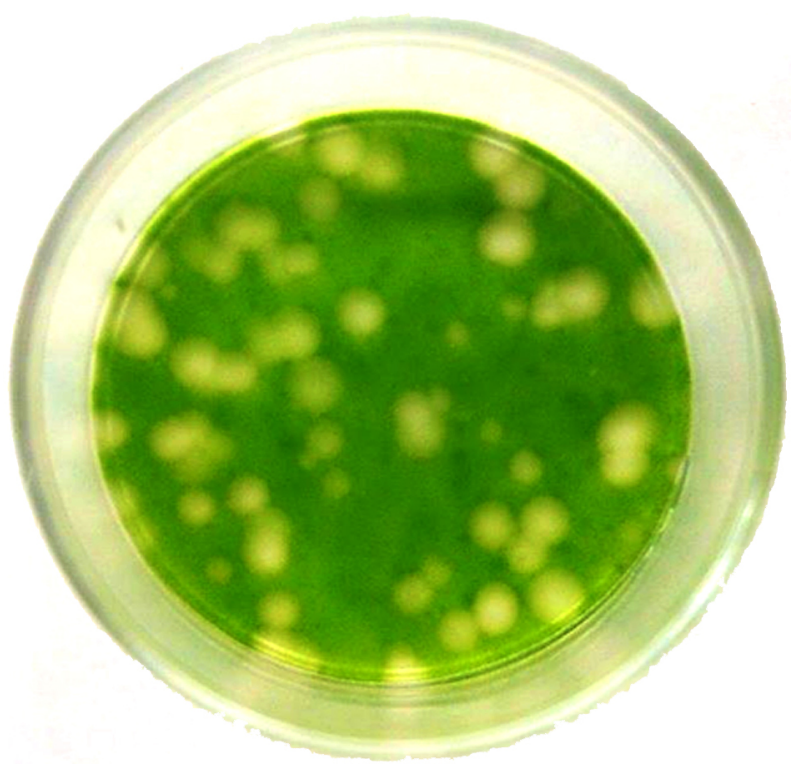

Fig. 3. Plaques (zones of lysis) produced on the lawn of zoochlorellae sensitive to PBCV.

the lawn of virus sensitive algae, plaques (zones of lysis) are produced (Fig. 3), and this empowers to calculate virus particles. In turn, infected liquid culture becomes transparent and opalescent.

Zoochlorellae can be obtained from the paramecia sampled in water bodies not contaminated with virus. They can persist for many decades without a spontaneous lysis as demonstrated by means of specific straining (Loefer, 1936). For instance, they have been stored for about 40 years at the culture collection of St. Petersburg State University (CALU; see: Pinevich et al., 2004).

Viruses suspended in culture medium do not interfere with the growth of Paramecium strains, and they do not threaten the safety of endosymbiotic zoochlorellae. However, as a rule, zoochlorellae cannot be isolated in culture anew - after release, they immediately become infected and lyse.

\section{Morphological diversity of algae inhabiting ciliates}

According to the available literature, paramecia can interact with more than a dozen of morphological types of algae. Upon engulfment, some of the algal cells are digested, while others become endosymbionts and can persist in this state for long; that was, e.g., demonstrated for a subset of 17 endosymbiotic algal strains originating from different hosts and geographic locations (Pröschold et al., 2011). Some of these zoochlorellae differed in morphology from common inhabitants of $C$. vulgaris and related species.

The strains of $P$. bursaria isolated from different regions of the Russian Federation harbored the algae morphologically similar to the well-known Micractinium conductrix NC64A and Chlorella variabilis 241-80 (Migunova, unpublished data). In contrast, some of the algal species that usually colonize wet rock surfaces have not been previously found in a symbiotic state, and they significantly differed from routine Keratococcus bicaudatus (by having crescent or spin-shaped cells with a "plunger" at one end). These algae, identified as Chlorolobion lunulatum, contained a single peripheral chloroplast with the pyrenoid surrounded by a solid starch enve-lope. Additionally, the rare ciliate Paramecium chlorelligerum was shown to harbor an alga preliminarily identified as Meyerella sp. (because it did not have a pyrenoid; Lanzoni et al., 2016). Noteworthy, the aforementioned algae of routine morphological types was not related to the tripartite symbiosis.

\section{Distribution of the symbiotic system}

Viruses of the PBCV type can be found often in fresh water pools (Van Etten et al., 1985; Reisser et al., 1986; Yamada et al., 1991, 1993; Kvitko et al., 1994, 1996a, 1996b; Migunova et al., 1996, 1999; Van Etten and Meints, 1999; Migunova, 2002). Their concentration is usually about $10^{4}$ plaque forming units (PFUs) per milliliter, although in the early spring and late autumn, the seasons of massive decline of ciliates, their concentration can reach $10^{13}$ PFU (Kvitko et al., 1994).

The American team (Van Etten et al., 1985) reported on the phycoviruses that selectively attacked zoochlorellae of the "American" strain Nc-64-A. In turn, the "Chinese" viruses were similar to the "American" counterparts (Zhang et al., 1988). By analogy, the strain NC-64-A supported viruses from the Japanese, Chinese, and Brazilian fresh water pools (Yamada et al., 1993).

The "German" viruses that showed specificity towards zoocxhlorellae of the West European strain Pbi did not infect the strain NC-64-A, and vice versa (Reisser et al., 1988), and they were similar to the virus described by the Russian authors (Kvitko and Gromov, 1984). 
Thus, the symbiotic association subdivides into two different ecotypes (Migunova, unpublished data), i.e., zoochlorellae can selectively inhabit the ciliates of the corresponding ecotype, and viruses can selectively infect only "their" zoochlorellae.

In the case of ciliate clones (Kvitko et al., 1996a, 1996b; Migunova et al., 1996, 1999, 2000; Migunova, 2002), the culture medium contained the viruses of only "north" or "south" ecotype (see below), or it was completely free of viruses.

The upper limit of $32^{\circ} \mathrm{C}$ for survival of "north" ecotype was in proof of correlation between geographical distribution of symbiotic system and local climate, and that empowered to rename the "American" and "European" ecotypes to the "south" and "north" ecotypes, correspondingly (Kvitko et al., 1996a, 1996b).

However, viruses of these ecotypes can be encountered outside the habitual geographical zones (Migunova, unpublished data). Thus, the virus of the "south" ecotype has not been found in water pools located above $45^{\circ} \mathrm{N}$, whereas the virus of the "north" ecotype has been rarely observed in water polls around $39^{\circ} \mathrm{N}$, e.g., in the Armenian mountains. As a rule, mountain regions are characterized by low temperature, and thus the Tajikistan, Kazakhstan, Uzbekistan, and Vet Nam mountain regions often harbored symbiotic systems of the "north" ecotype.

Co-occurrence of the viruses of both ecotypes was observed only twice - in the Astrakhan city environs (the Caspian Sea region), and at the Curonian Spit (the Baltic Sea region). Both these locations represent stopping places for migratory birds that are the vectors for distant transfer of microbes among water pools. However, in the above cases, it was the issue of temporary fluctuations; in fact, the representatives of the "south" ecotype cannot tolerate cold winters (Migunova et al., 1999; Migunova, 2002).

The algae of the "north" ecotype are usually identified as Micractinium conductrix while those of the "south" ecotype belong to the species Chlorella variabilis. It is also generally considered that there are two specific viruses, as well as two ecotypes of ciliates infected by the corresponding algae. Each ecotype probably encompasses the ciliates that belong to several syngens with different mating types, and thus they never mutually intermix.

\section{Sugars excretion by zoochlorellae}

Sugars (simple carbohydrates) excretion is essential for formation and maintenance of symbioses between ciliates and microalgae (Weis, 1979, 1980). Cell membrane involved in the process of phagocytosis contains receptors for glucose and maltose, in particular. In turn, maltose and trehalose act as inhibitors of fusion between phagosome and lysosome. Within a phagosome (in this case, it is an early perialgal vacuole), early zoochlorella excretes maltose or glucose, depending on the species. The sugar binds to receptor at phagosome membrane, and this receptor transmits the signal to response regulator which induces the formation of specific "microclimate" for the algal cell. Thus, the early perialgal vacuole converts to the late perialgal vacuole with $\mathrm{pH}$ of 4.0-4.5 (the value beneficial for photosynthesis and sugar excretion). After ca. $24 \mathrm{~h}$, zoochlorellae begin to divide, and this indicates the final establishing of endosymbiotic relationships. Sugars excretion analyzed in the experiments with zoochlorellae strains (Gaponova et al., 2004; Migunova, unpublished data) has shown qualitative distinction between the "north" and "south" strains. Besides, sugars were excreted only if zoochlorellae grew in a mineral-organic medium containing aminopeptide. In contrast, sugars have been never excreted by zoochlorellae cultured in a mineral medium.

\section{Restoration of symbiotic system using algal strains marked with a resistance to antibiotics}

A separate task of K. Kvitko' group was to create a collection of zoochlorellae marked with a resistance to antibiotics. Generally, such collection could be used in testing a potential ability for transduction, as well as for construing artificial symbiotic associations, and detailed analyses of symbiotic relationships. After preliminary choice of algae for sensitivity to antibiotics, as well as after finding drug concentrations that did not affect the virus, the collection had been successfully created. The sensitivity to streptomycin, the inhibitor of $70 \mathrm{~S}$ translation, and to canavanine, a toxic analog of arginine, was among the major selective markers (Kvitko et al., 1988; Migunova, unpublished data). 
A

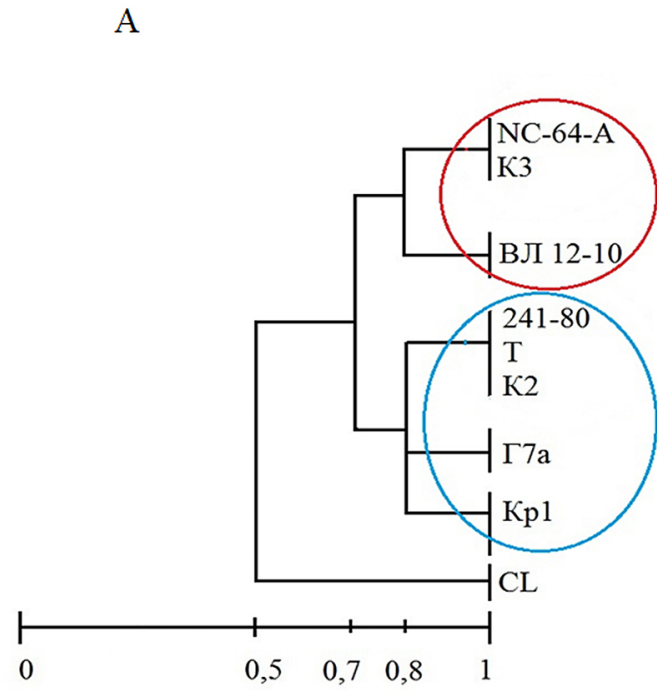

B

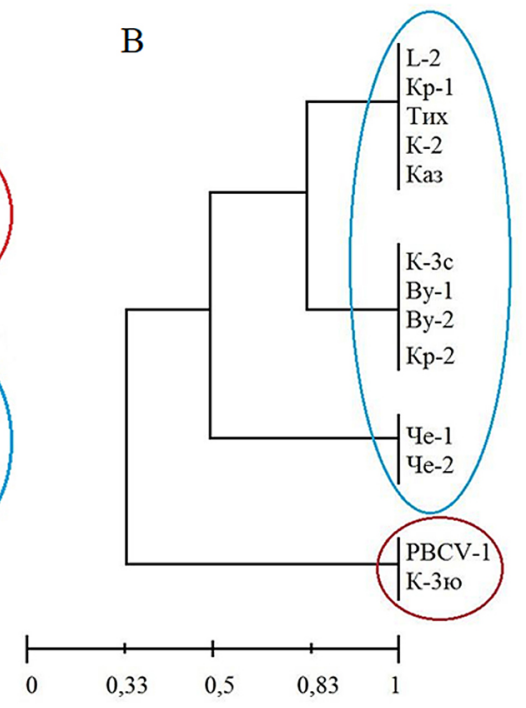

Fig. 4. Evolutionary trees of zoochlorellae (A) and PBCV (B) reconstructed based on the data of PAAG electrophoresis of total protein. "North" zoochlorellae circumscribed in blue, "south" zoochlorellae circumscribed in red. Graded bar, conventional phylogenetic distance.

The obtained marked lines have been used in the current experiments on restoration of symbiotic relationships (Migunova, unpublished data). In particular, paramecia were cured from their photosynthetic symbionts (via a two-month storage in darkness), and then infected with multi-marked algal strains of both ecotypes simultaneously (the sets of markers differed in the "north" and "south" strains, respectively). Upon restoration of the symbiosis, algae were repeatedly isolated, and stable infection with the same ecotype was confirmed. Marked zoochlorellae were also used by the colleague-protistologist (Karpov, 1999) in the experiments on artificial symbiotic associations, with participation of amoebae.

\section{Serologic diagnostics of zoochlorellae}

For this purpose, rabbit and hen antiserums to collection strains of zoochlorellae, as well as to their viruses, have been obtained (Migunova et al., 1992; Migunova, 2002). In order to find relatedness between novel zoochlorellae clones, different serological methods were employed, such as immunoagglutination, immunoprecipitation, and immunofluorescence. Additionally, antiserums were used in search of relatedness between collection strains, as well as for search of novel zoochlorellae and their viruses in environmental water samples (Migunova et al., 1992; Migunova, 2002). In particular, basing on the immunofluorescence method, one could demonstrate that the virus was absorbed at cell surface of ciliates (Yashchenko, 2009). Noteworthy, it was possible to correlate with the $100 \%$ probability the sensitivity to virus with: i) immunoagglutination titer; ii) antiserum to specific Chlorella ecotypes; iii) immunoprecipitate homology; iv) immunofluorescence and immunoblotting data (Migunova, 2002). As the result, two alternate variants of surface antigens in zoochlorellae were discovered (in the "south" and "north" ecotypes, respectively), and they correlated with the specific sensitivity to viruses of the corresponding ecotypes. These antigens differed from those in free-living chlorellae resistant to PBCV-type viruses.

\section{Protein composition and genotyping data}

The relatedness between clones of zoochlorellae has been initially evaluated basing on a comparison of PAG spectra of total cell proteins; the obtained data were presented in the form of dendrograms (Fig. 4, A). This approach was also employed in the study of relatedness between PBCV viruses (Fig. 4, B). 


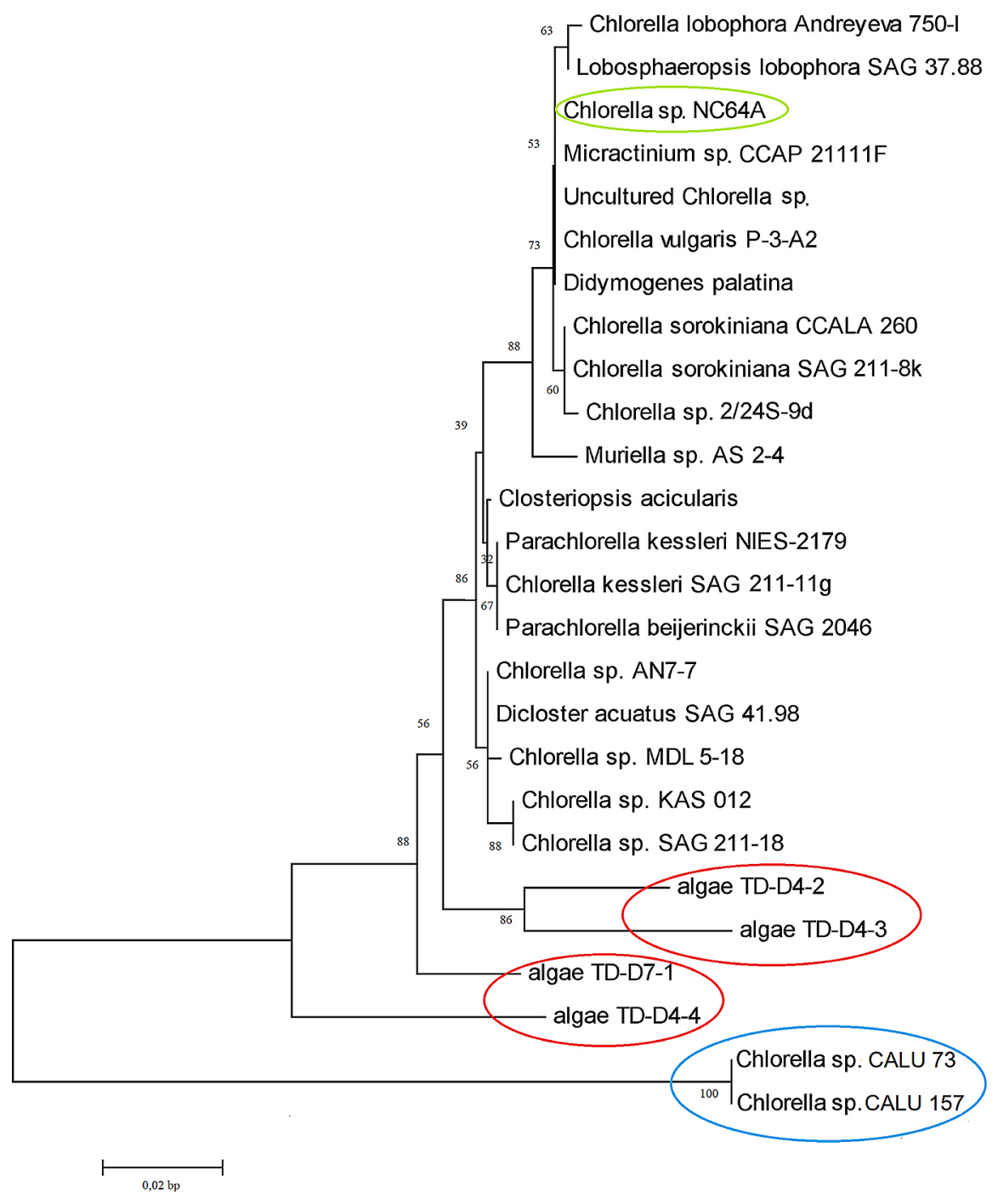

Fig. 5. The 18S rRNA gene tree of Chlorella-like algae reconstructed by Maximum Likelihood method. Algal clones isolated from Tajik strain ciliates circumscribed in red; free-living algal strains CALU-73 circumscribed in blue, "north" ecotype zoochlorellae strain NC64A circumscribed in green. Bootstrap values are shown at nodes.

The relatedness of the newly found zoochlorellae to the type strains was also tested by means of $18 \mathrm{~S}$ rRNA gene sequencing (Fig. 5) (Kvitko et al., 2001; Migunova, 2002; Kvitko et al., 2004; Gaponova et al., 2006).

Additionally, two zoochlorellae ecotypes demonstrated different domain structure of the $18 \mathrm{~S}$ rRNA gene (Fig. 6). Thus, the "south" ecotype contained three introns while the "north" ecotype had only one. This distinction has been confirmed for numerous strains, and it has been used as a phylogenetic marker (Kvitko et al., 2001; Gaponova et al., 2006; Hoshina et al., 2008). An exception was observed in the zoochlorellae from the "south" Tajik clone T-24-5 ciliates - four introns (Vorobyev et al.,
2006, 2008). This is not the only unusual property of Tajik tripartite symbiotic systems: although they belong to the "south" ecotype, their ciliates belong to a common syngene with the "north" ecotype. In perspective, Tajik samples would provide valuable information on the origin and evolution of tripartite symbiotic systems.

\section{Ecological role and evolutionary significance of PBCV}

Although the function of $\mathrm{PBCV}$ in the tripartite symbiosis is far from being completely clear, three aspects could be considered with certainty. 
18S rRNA gene

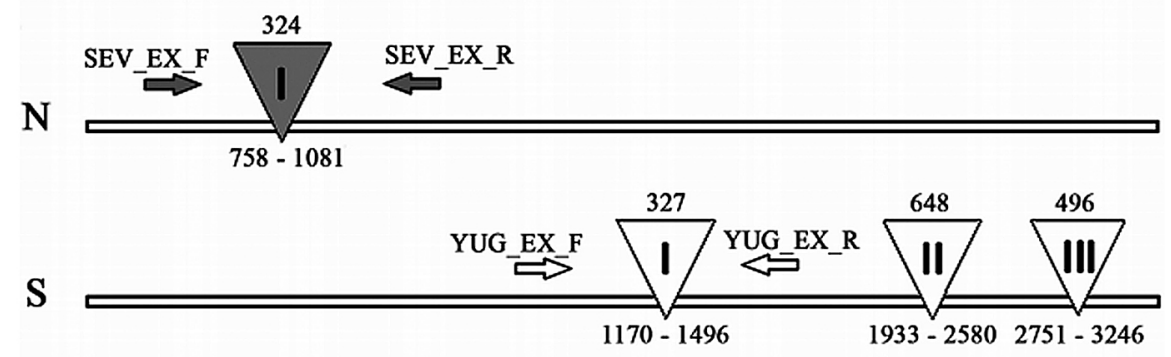

Fig. 6. Location and size (bp) of the introns in two ecotypes of symbiotic Chlorella (from: Vorobyev et al., 2006). N - Single intron in "north" zoochlorellae; S - three introns in "south" zoochlorellae. Arrows denote 18S rDNA primers used for the amplification of introns. Sites of intron insertion are as in Chlorella kessleri SAG211-11g (X56105). See the text for explanation.

Participation in microbial loop. It is well known that marine lytic viruses promote fast release of the soluble organic matter, which helps to redistribute biogenic elements needed by primary producers (Azam et al., 1983). Unfortunately, this ecological aspect has not been quantitatively analyzed regarding freshwater or soil viruses, in general, and viruses in tripartite symbiotic system, in particular.

Control for size of host population. The DNA of PBCV contains ARS-like segments that ensure viral replication within eukaryotic cells (Girton et al., 1984). Lytic cycle of PBCV is routine in that it starts from absorption on live host cell, and finishes with cell death. Intermediate stages (membrane fusion, DNA targeting to the nucleus, transcription of early genes, replication of viral genome, expression of late genes, virion assembly) are also more or less trivial. However, in addition to this common strategy, PBCV carries a specific protein attractant for ciliates (Dunigan et al., 2019; Van Etten et al., 2020). In other words, the virus "actively" finds the right place and the right time for attack on released zoochlorellae. To a large extent, such predatory behavior defines the ecological role of PBCV. The virus optimally controls host's ontogeny and population size (zoochlorellae are absent in freeliving state); additionally, this strategy is beneficial for maintaining the abundance and distribution of the virus itself.

Genetic vector. Participation of PBCV in horizontal gene transfer could possibly influence the host's evolution. The virus presumably persists in lysogenic state within the algal population; at inducing stimuli it turns into a vector which transfers genetic information between algal cells. One can also propose that parental symbiosis could contain zoochlorellae of only one type, while during co-evolution with the virus, multiple forms of zoochlorellae appeared. They could differ from one another in such ecological trait as thermal dependence, which was important for spatial expansion and ecotype formation. In other words, the "north" and "south" ecotypes could originate with an aid of the virus. Importantly, zoochlorellae and their viruses contain ecotype-specific introns (see above). The observed polymorphism of exonintron structure of the 18S rRNA gene could be due to horizontal transfer mediated by PBCV.

\section{Practical implications of PBCV}

Starting from initial analyses, the tripartite symbiosis has been considered a convenient model for safe testing of potentially harmful environmental agents (Kvitko et al., 1994). In particular, this system was recommended as a potential sensor of water quality, while PBCV itself could represent a safe substitute for pathogenic viruses in test systems dealing with medicines' validation. For example, PBCV was offered as a surrogate of human adenovirus in the UV-based systems of water purity testing (Sun et al., 2020).

Unfortunately, there is a probability that even a "virgin" virus can be potentially hazardous, such danger being demonstrated in the case of Acanthocystis turfacea Chlorella virus (ATCV). This PBCVsimilar virus infects zoochlorellae of the heliozoan A. turfacea (Yolken et al., 2014; Van Etten et al., 2020). It was discovered during the analyses of throat microbiomes in the patients suffering from mental dysfunctions. As compared with healthy volunteers, their cognitive abilities (e.g., processing visual information, fixing attention) were $10 \%$ 
lower and did not correlate with gender, age, nationality and other personal characters (Yolken et al., 2014). It was supposed that ATCV influenced brain function indirectly - by promoting the effects of infectious microbes or heavy metal pollution. Similar cognitive problems have been observed in the experiments with mice (Yolken et al., 2014), but in this case, the level of expression of 1,300 genes in hippocampus (the zone responsible for memory and space orientation) was affected. Although ATCV has not been found in animal brain tissues, it was proposed to influence this organ indirectly via the immune system.

\section{Conclusion}

The tripartite symbiotic system, in which once B. Gromov was interested and which has been long investigated by K. Kvitko and his colleagues, is important from the viewpoints of: i) regulatory and metabolic foundations of the endosymbiosis between ciliates and zoochlorellae, ii) specific strategy of PBCV infection, iii) co-evolution of PBCV with host, iv) the role of $\mathrm{PBCV}$ in population ecology of ciliates, as well as in the abundance and distribution of the virus itself, v) practical significance of a symbiotic system in general, and $\mathrm{PBCV}$, in particular. Moreover, viruses of the NCLDV group can be considered in relation to the ambitious hypotheses on the phylogeny of viruses, as well as for construing the evolutionary scenarios of the cellular life origin (Koonin and Yutin, 2019).

\section{Acknowledgements}

Fruitful collaboration with A.M. by N. Ordjan (1989), T. Hong (2006), K. Vorobyev (2008), O. Matantseva (2009), Yu. Stepanova (2011), E. Vasilieva (2013) and O. Platonova (2017) is gratefully acknowledged. The comments by an anonymous Reviewer are acknowledged with gratitude.

\section{References}

Azam F., Fenchel T., Field J.G. et al. 1983. The ecological role of water-column microbes in the sea. Mar. Ecol. Progr. Ser. 10, 257-263.

Dunigan D.D., Al-Sammak M., Al-Ameeli Z. et al. 2019. Chloroviruses lure hosts through longdistance chemical signaling. J. Virol. 93, e01688-18.
Gaponova I.N., Andronov E.E., Migunova A.V. et al. 2006. Genomic dactyloscopy of Chlorella sp. - symbionts of Paramecium bursaria. Protistology. 4, 311-317.

Gaponova I.N., Migunova A.V. and Kvitko K.V. 2004. Study of sugars secretion in north zoochlorellae - symbionts of Paramecium bursaria in vivo and in vitro. Vestnik LGU, Ser. biol. 3 (4), 76-80 (in Russian with English summary).

Girton L.E., Osterman J.S. and Van Etten J.L. 1984. DNA segments of the algae virus, PBCV-1, capable of autonomous replication in Saccharomyces cerevisiae. Genetics. 107, 38.

Hoshina R. and Imamura N. 2008. Eu-Chlorella large subunit rDNA sequences and group I introns in ribosomal DNA of the paramecian symbiotic alga NC64A. Phycol. Res. 2008. 56, 21-32.

Karpov A.S. 1999. Establishing and some properties of artificial endocytobiotic association between amoebae and chlorellae. PhD Thesis. Institute of Cytology RAS. St. Petersburg (in Russian).

Kawakami H. and Kawakami N. 1978. Behavior of a virus in a symbiotic system, Paramecium bursaria-zoochlorella. 1978. J. Protozool. 25, 217 -225 .

Koonin E.V. and Yutin N. 2019. Evolution of the large nucleocytoplasmic DNA viruses of eukaryotes and convergent origins of viral gigantism. Adv. Virus Res. 103, 167-202.

Kvitko K.V. and Gromov B.V. 1984. New findings of a titrated infectious virus in the zoochlorella. Doklady Academii Nauk SSSR. 279, 998-999 (in Russian with English summary).

Kvitko K.V., Kraeva E.S. and Chernysheva A.V. 1988. Genetic marking of zoochlorellae - hosts of the PBCV viruses. Vestnik LGU, Ser. biol. 3 (1), 120-124 (in Russian with English summary).

Kvitko K.V., Migunova A.V., Gaponova I.I. et al. 2004. Population variability of the tripartite symbiotic system: Paramecium bursaria, zoochlorella, and its viruses. Ecol. Genet. 2, 29-39.

Kvitko K.V., Migunova A.V., Karelov D.V. and Prokosheva M.Ju. 2001. Molecular taxonomy of virus-sensitive Chlorella sp. - symbionts of Paramecium bursaria. 2001. Protistology. 2, 96-104.

Kvitko K.V., Vojtsechovsky E.V., Migunova A.V. et al. 1994. Population variability of agamic zoochlorellae and their viruses. Abstr. Conf. Appl. Genet. Microorg. Genetics (Suppl.). 30, 68.

Kvitko K., Zelennikova O., Migunova A. et al. 1996a. Variability of Chlorella sp., symbionts of Paramecium bursaria and their viruses (PBCV). Genetics, geography and ecology of a symbiotic sys- 
tem. Abstr. VII Intern. Conf. Cell and Mol. Biol. of Chlamydomonas. Regensburg. P. 104.

Kvitko K.V., Zelennikova O., Migunova A.V. et al. 1996b. Ecological and climatic rules for PBCVvirus circulation. Abstr. X Intern. Congr. Virol. Jerusalem. P. 250.

Lanzoni O., Fokin S.I., Lebedeva N. et al. 2016. Rare freshwater ciliate Paramecium chlorelligerum Kahl, 1935 and its macronuclear symbiotic bacterium "Candidatus Holospora parva". PLoS ONE. DOI:10.1371/journal.pone.0167928.

Loefer J.B. 1936. Isolation and growth characteristics of the zoochlorella of Paramecium bursaria. Amer. Nat. 70, 184-188.

Migunova A.V. 2002. Study of algae in the symbiotic system: Paramecium bursaria-Chlorella sp. -virus PBCV (Phycodnaviridae). PhD Thesis. St. Petersburg State University. St. Petersburg (in Russian).

Migunova A.V., Kvitko K.V. and Knjazeva N.V. 1992. Variability of serological characters in the marked strains of zoochlorellae - symbionts of Paramecium bursaria sensitive to virus. Algology. 2, 43-48.

Migunova A.V., Kvitko K.V., Prokosheva M.Yu. and Litvinov D.B. 2000. Influence of temperature on the development of Paramecium bursaria, Chlorella and PBCV-1 viruses in the tripartite symbiosis system. Vestnik LGU, Ser. biol. 3 (1), 65-75 (in Russian with English summary).

Migunova A.V., Kvitko K.V., Skoblo I.I. et al. 1999. Ecology of the symbiotic system: Paramecium bursaria-Chlorella-virus. Vestnik LGU, Ser. biol. 3 (17), 131-144 (in Russian with English summary).

Migunova A., Scoblo I., Kraeva E. et al. 1996. Zoochlorella viruses carrier status of Paramecium bursaria. Abstr. X Intern. Congr. Virol. Jerusalem. P. 251.

Pinevich A.V., Mamkaeva K.A., Titova N.N. et al. 2004. St. Petersburg Culture Collection (CALU): four decades of storage and research with microscopic algae, cyanobacteria and other microorganisms. Nova Hedwigia. 79, 115-126.

Pröschold T., Darienko T., Silva P.C. et al. 2011. The systematics of zoochlorella revisited employing an integrative approach. Environ. Microbiol. 13, 350-364.

Reisser W. 1980. The metabolic interaction between Paramecium bursaria Ehrbg. and Chlorella sp. in the P. bursaria symbiosis. Arch. Microbiol. 125, 291-293.

Reisser W., Becker B. and Klein T. 1986. Studies on ultrastructure and host range of a Chlorella attacking virus. Protoplasma. 135, 162-165.
Reisser W., Klein T. and Becker B. 1988. Studies of phycoviruses I. On the ecology of viruses attacking Chlorella exsymbiotic from an European strain of Paramecium bursaria. Arch. Hydrobiol. 111, 575-583.

Sun Z., Fu J., Li X. et al. 2020. Using algal virus Paramecium bursaria Chlorella virus as a human adenovirus surrogate for validation of UV treatment systems. Environ. Sci. Technol. 54, 15507-15515.

Van Etten J.L., Agarkova I.V. and Dunigan D.D. 2020. Chloroviruses. Viruses. 12, 20.

Van Etten J.L. and Meints R.H. 1999. Giant viruses infecting algae. Annu. Rev. Microbiol. 53, 447-494.

Van Etten J.L., Meints R.H., Burbank D.E. et al. 1981. Isolation and characterization of a virus from the intracellular green alga symbiotic with Hydra viridis. Virology. 113, 704-711.

Van Etten J.L., Van Etten C.H., Jonson J.K. and Burbank D.E. 1985. A survey for viruses from fresh water that infect a eukaryotic Chlorella-like green alga. Appl. Environ. Microbiol. 49, 1326-1328.

Vorobyev K., Andronov E., Rautian M. et al. 2009. An atypical Chlorella symbiont from Paramecium bursaria. Protistology. 6, 39-44.

Vorobyev K.P., Migunova A.V., Chizhevskaya E.P. et al. 2006. Introns in the $18 \mathrm{~S}$ rRNA gene of zoochlorellae, the symbionts of Paramecium bursaria, and perspectives of their use in systematics. Vestnik LGU, Ser. biol. 3 (4). 98-108 (in Russian with English summary).

Weis D.S. 1979. Correlation of sugar release and concanavalin-A agglutinability with infectivity of symbiotic algae from Paramecium bursaria for aposymbiotic $P$. bursaria. J. Protozool. 26, 117-119.

Weis D.S. 1980. Hypothesis: free maltose and algal cell surface sugars are signals in the infection of Paramecium bursaria by algae. Endocytobiol. Endosymb. Cell Biol. 1, 105-112.

Yamada T., Higashiyama T. and Fukuda T. 1991. Screening of natural waters for viruses which infect Chlorella cells. Appl. Environ. Microbiol. 57, 3433-3437.

Yamada T., Shimomae A., Furukawa S. and Takechara J. 1993. Widespread distribution of Chlorella viruses in Japan. Biosci. Biotech. Biochem. 57, 733-739.

Yashchenko V.V. 2009. Interactions between Paramecium bursaria (Ciliophora) and viruses of zoochlorellae (Phycodnaviridae) in the tripartite symbiotic system Paramecium bursaria-Chlorella sp.-virus). PhD Thesis. St. Petersburg State University. St. Petersburg (in Russian). 
152 - Alexandra Migunova and Alexander Pinevich

Yashchenko V.V., Gavrilova O.V., Rautian M.S. and Jakobsen K.S. 2012. Association of Paramecium bursaria chlorella viruses with Paramecium bursaria cells: ultrastructural studies. Eur. J. Protistol. 48, 149-159.

Yolken R.H., Jones-Brando L., Dunigan D.D. et al. 2014. Chlorovirus ATCV-1 is part of the human oropharyngeal virome and is associated with changes in cognitive functions in humans and mice. Proc. Natl. Acad. Sci. USA. 111, 16106-16111.

Zhang Y., Burbank D.E. and Van Etten J.L. 1988. Chlorella viruses isolated in China. Appl. Environ. Microbiol. 54, 2170-2173.

Address for correspondence: Alexandra Migunova. Department of Microbiology, St. Petersburg State University, Universitetskaya Emb.7/9, 199034 St. Petersburg, Russia; e-mail: sasha_mig_2405@mail.ru 